\title{
自律校正法によるロバストなセンシング技術*
}

\section{清野 慧**}

Robust Sensing in Metrology with In-Situ Self-Calibration / Satoshi KIYONO

Key words: calibration, self-calibration, in-situ calibration, displacement sensor, nano-metrology

\section{1.は・じめに}

製品の許容公差がミクロン，サブミクロンになり，それ を保証する精密測定にはナノメートルレベルの精度が要求 される場合が増えつつある。この領域での精密測定には今 まで以上のロバスト性が求められ，しかもその実現に困難 が増している，例えば精密な形状計測において，加工への フィードバックという観点からは加工と計測における加工 物の保持を含めた環境の同一性が必要となり，さらに，そ の加工物を目的のシステムに組み込む環境での変形を含め た形状が評価できなければならない。

精密計測のロバスト性にとって考慮すべき事項は，測定 対象, 測定の基準, 両者を比較する際のセンサの安定性で ある. 測定基準に関しては, 測定が加工機上で行われるこ とからその基準の確からしさをどのように保証するかが問 題であり，七ンサにとっては校正結果を使った補正を含め た安定性が課題になる。本稿では, 高精度が要求される機 上測定を念頭においた精密計測にとってのセンサの校正法 をロバスト性の観点からまとめる.

\section{2. センサの校正の必要性とその要求精度 ${ }^{1)}$}

図 1 は変位センサの校正曲線の例を示す。一般に市販 されているセンサは网 1 の平均的感度を示す直線とそのば らつきの幅が知らされるだけで, 四の校正曲線の詳細（平 均感度からの偏差で, 以下では線形誤差と呼ぶ）は不明で ある。ところが，機械の基準となる真直形状や真円形状の 精密測定には, 平均感度よりもこの線形誤差が重要な意味 をもつことが多い，それは，平均感度がスケールファク夕

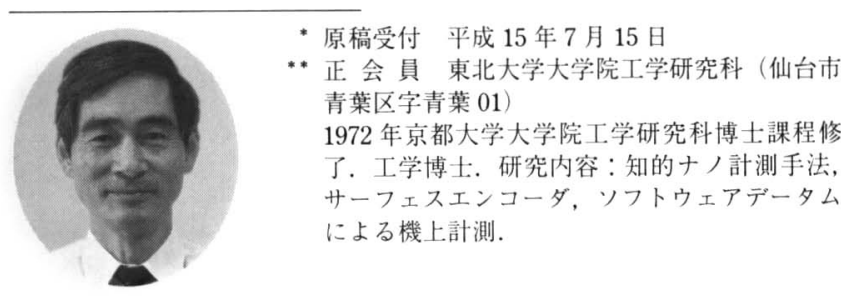

として作用し, 真直形状の誤差評価にはあまり影響がない のに対し, 線形誤差が加算的に影響するためである.

図 2 は線形誤差の影響を模式的に示したもので, 測定 に用いられたセンサの出力範囲に含まれる線形誤差が真直 形状に和として加わることになる.

例えば，測定対象に対する走査方向の傾斜のためにセン サ出力が $1 \mu \mathrm{m}$ の幅で変化し, その範囲に $10 \mathrm{~nm}$ (出力範 囲の $1 \%$ ）の線形誤差があると, その $10 \mathrm{~nm}$ が真直形状に 和として加わることになる.この場合は, 形状精度が高く なるほどその影響が重大になる，したがって，形状測定に 用いるセンサを性能いっぱいまで使うには, ユーザが線形 誤差を校正し, 補正する必要がある.

真円度測定における 3 点法, 真直度測定における 2 点法 など, 複数の変位センサを用いて走查運動の誤差を取り除 く方法においては, 校正誤差の影響はより顕著であること が知られている ${ }^{233}$. この場合, 複数のセンサに共通の公称 感度がスケールの役割を果たし, 個々の校正誤差 (平均感 度誤差と線形誤差を合わせたもの）の差が加算的に 2 点 法, 3 点法の差動出力に影響する.

\section{3. 精密形状測定とセンサの校正}

\section{1 高精度基準との比較校正}

変位センサの従来の校正法は, より確かな変位センサと

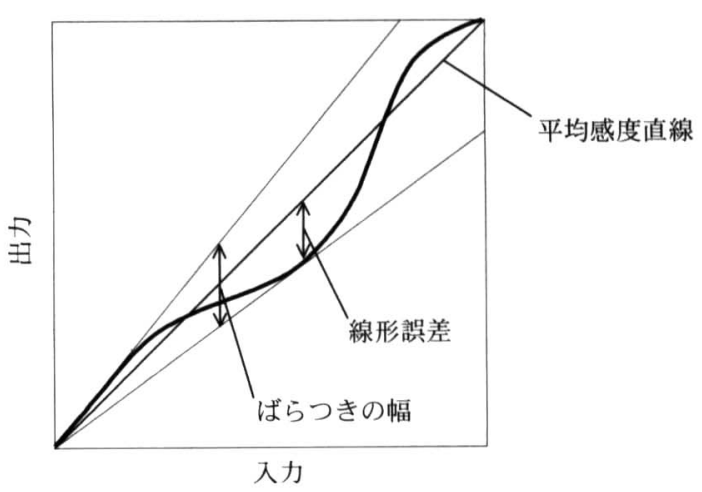

図 1 校正曲線の例 


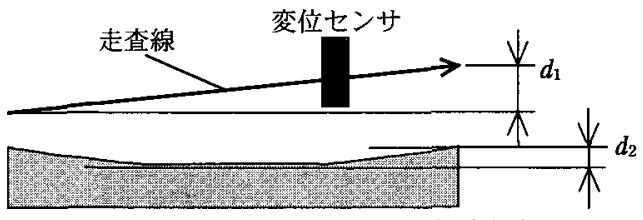

測定対奥
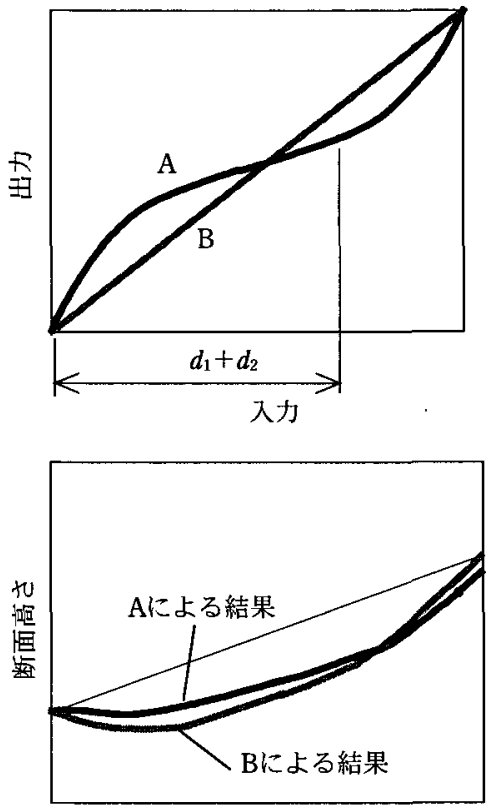

位置

図 2 線形誤差のもたらす影偣

の比較校正である．基準として用いられる最も精度の高い 変位検出器として結晶格子の間隔を $\mathrm{X}$ 線干涉計で読みと るシステムが実用されている4!

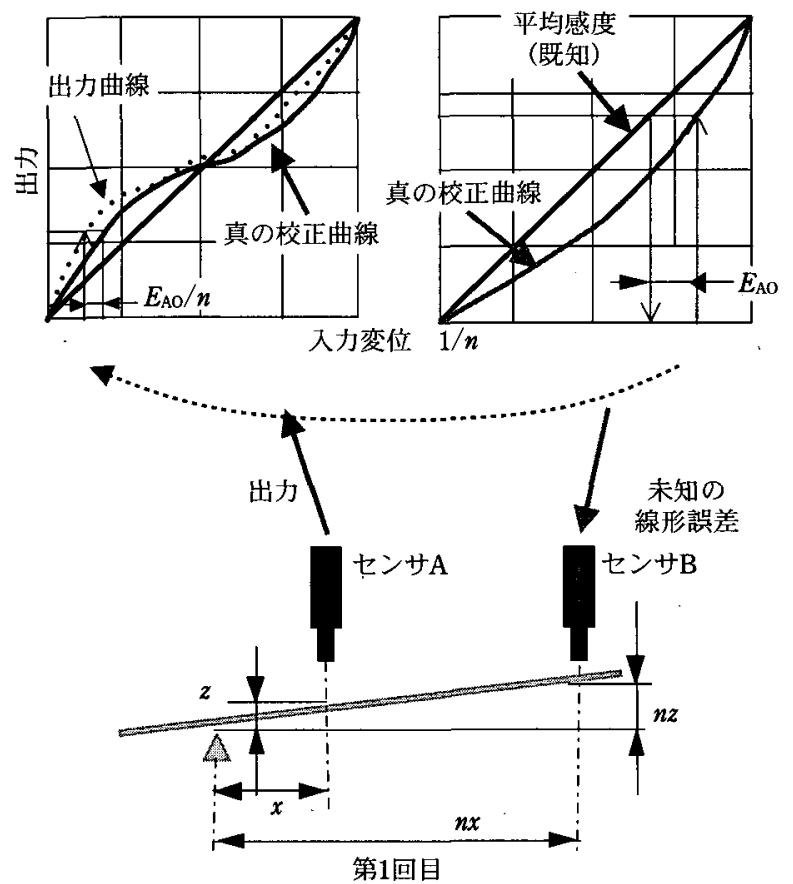

測定機に組み込まれて変位計を校正するには，校正され 值付けされた段差試料などが，測定範囲の一部を代表する 一種の平均感度を校正するのに使われる。この場合，一般 に線形誤差は校正されない.

\section{2 自律校正法”}

\section{2 .1 一対のセンサ}

図 3 は同程度の精度を有する一対のセンサによる自律 校正法を示す ${ }^{5)}$. 最初に基準に使うセンサの平均感度を既 知とする. 被校正側センサ $\mathrm{A}$ の変位がレバーで $n$ 倍され る位置に校正側センサ B を配置して, センサ Bでセンサ $\mathrm{A}$ の入力変位を評価することで校正すると，センサ Bの 未知の線形誤差が $1 / n$ 倍されてセンサ $\mathrm{A} の$ 校正結果に含 まれることになる.この第 1 回の校正結果を得た後，両七 ンサの配置を逆にして同様の校正をすると，センサBの 校正曲線が得られ，その結果には，当初未知であったセン サ B の線形誤差が $(1 / n)^{2}$ 倍されて含まれる。この校正 デー夕を使って，直前のデー夕を修正することができ，そ の修正を繰り返すと両センサについて正しい校正結果が得 られる。

3.2 .2 校正曲線の導関数の測定 ${ }^{6)}$

図 4 は単独のセンサの自律校正法を示す。センサの ターゲットを圧電素子 1（PZT1）で全校正範囲にわたっ て移動し，各点での出力をとる，そのとき，圧電素子 2 (PZT2) の一定入力電压をオン，オフして一定変位 $D$ を 与えると, 各点で $Z_{i}$ と $Z_{i}+D$ の入力に対する出力, $V_{i}, V_{i+}$ が得られる. したがってこの出力の差と $D$ の比から校正 曲線の逆関数 $f^{-1}(V)$ の導関数が得られる.

図 5 はこれらの方法で得た校正結果の例を示す. 両者
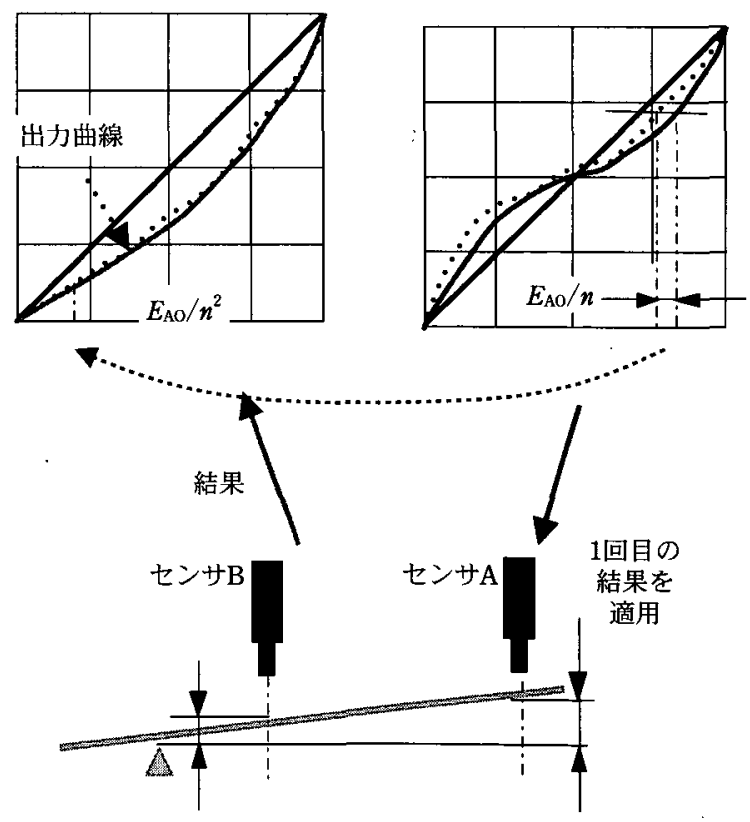

第2回目

图 32 2つのセンサによる自律校正原理 


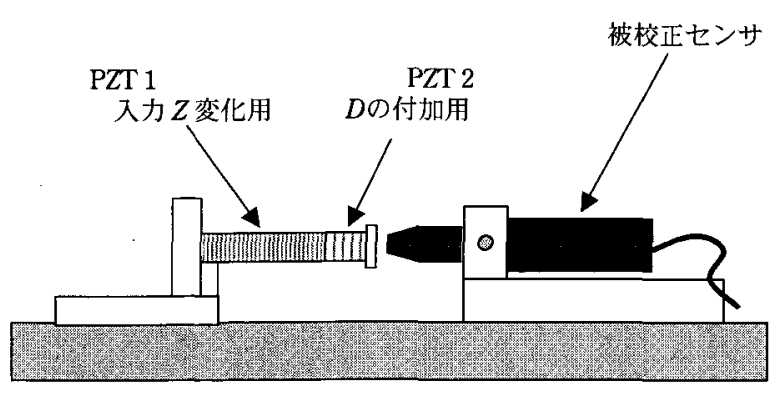

图 4 単独センサの自律校正法

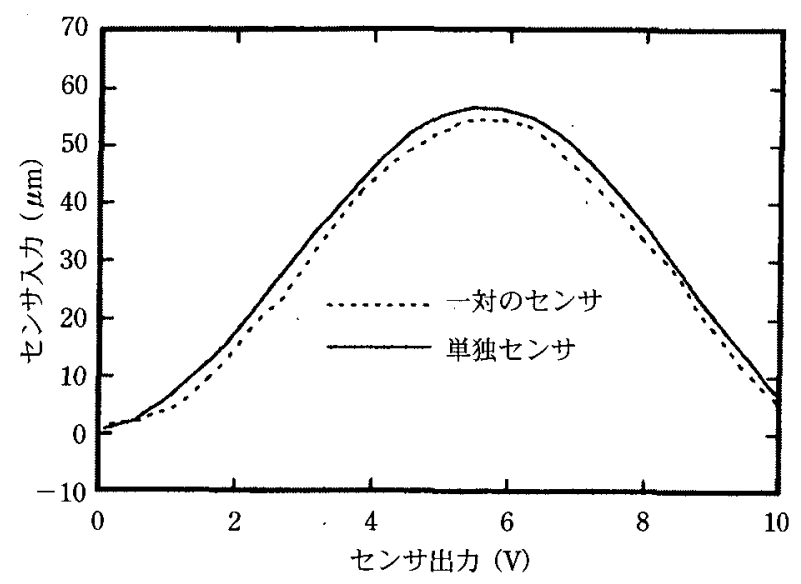

目 5 自律校正結果の比較

はよい一致を示している。すなわち，いずれの方法をとる にしても，線形誤差が未知であったための不確かさは $1 / 10$ 程度には低減されることがわかる.

3.2.3 計測のためのデー夕によるその場校正”

形状測定機に組み込んだ変位センサの校正をするには, この導関数を求める手法が有效である，その手順では，図 6 に示すように，一度形状測定をした後，試料あるいは変 位センサを形状高さ方向に $D$ だけシフトして再度測定す る. 同じ $x$ の位置での 1 回目と 2 回目のセンサ入力の差 は $D$ であり，2回のセンサ出力の差で $D$ を除すと， $D /\left\{V_{+}(x)-V(x)\right\}$ の形で微係数が求まる. 求まった微 係数を $V$ の値の小さい順に並べれば先の図 4 と同様の導 関数が求まり，これを皘分すれば校正曲線がその場で得ら れる.つまり，この手法によれば，形状測定の絽り返し性 を確認するとともに，その繰り返し誤差とほほ同程度のレ ベルでセンサの線形誤差の補正值を得ることになる。な お, この場合, 2 回の測定における走查運動誤差 $E(x)$ の 違いは無視している。

図 7 は図 4 の方式と, 図 6 の方式で容量型変位センサ を校正した結果で，両者が十分よい一致をみているといえ る.

\section{4. 校正法による不確かさの違い}

\section{1 校正結果の不確かさ}

上述の各種校正法の不確かさを定量的に表すことは難し

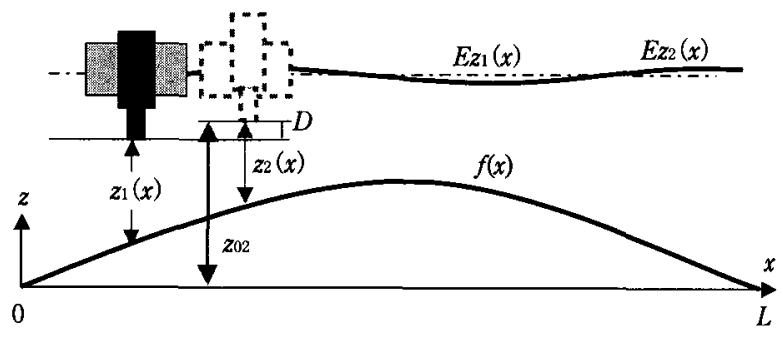

图 6 その場校正法の原理

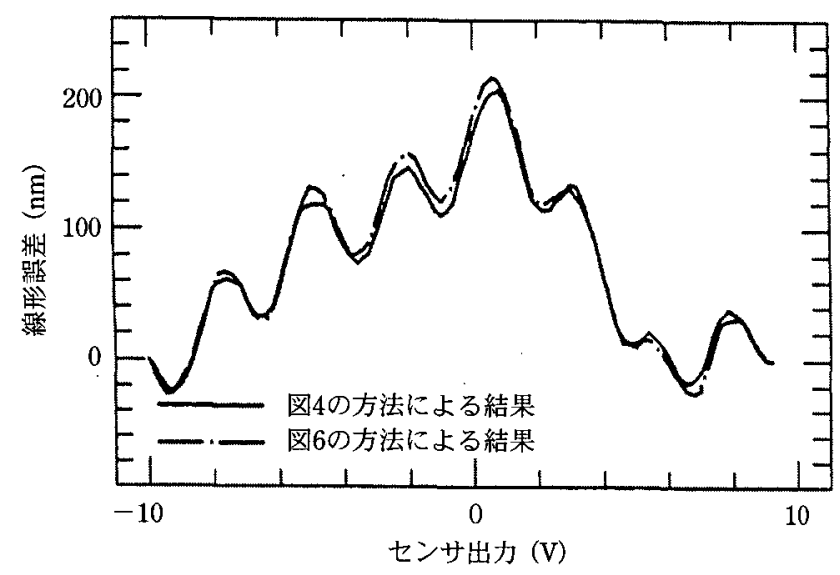

図 7 単独センサの校正とその場校正

い.ここでは， $\mathrm{nm}$ 領域での使用を前提にしたセンサに 限って定性的な比較を行ってみる。センサの有する不確か さをもたらす要因には，未知の線形誤差，分解能，センサ の不安定性がある。校正結果の不確かさには，どれだけ詳 細に線形誤差が同定できるかということにかかっているた め，上述の各種の校正法による結果の不確かさは定性的に 图8のように表される ${ }^{1}$. 一対のセンサによる自律校正で は, セン州交換のための再取付け，レバーの支点のわずか な移動などが線形誤差の同定に抢ける不確かさの要因とな る. 図 4 の単独センサの自律校正システムでは，Dの一 定性が結果を左右する．段差試料で $D$ を与えれば，段差 を測定するたびにたいていの場合必要になる横方向の走査 の繰り返し性が, 压電素子（PZT）などのアクチュエータ で $D$ を与えるときには，その繰り返し精度が重要な不確 かさの要因になる。形状測定デー夕を使うその場校正法で は，図中の 3 つの要因が分離できないが，他の場合との比 較のため分けて示した。したがって，この場合の線形誤差 の項は測定の走查運動の繰り返し誤差が主な不確定要因に なる.

これら自律的な校正法の不確かさの大きさに関する順位 は必ずしも一般性があるわけではないが, 校正データを得 るだけが目的の場合，高精度の基準を用いた比較校正の確 からしさに勝るものはない。

しかし，一般のユーザにとって，校正の目的はその結果 を計測データの補正に用いることであり，補正に用いる際 


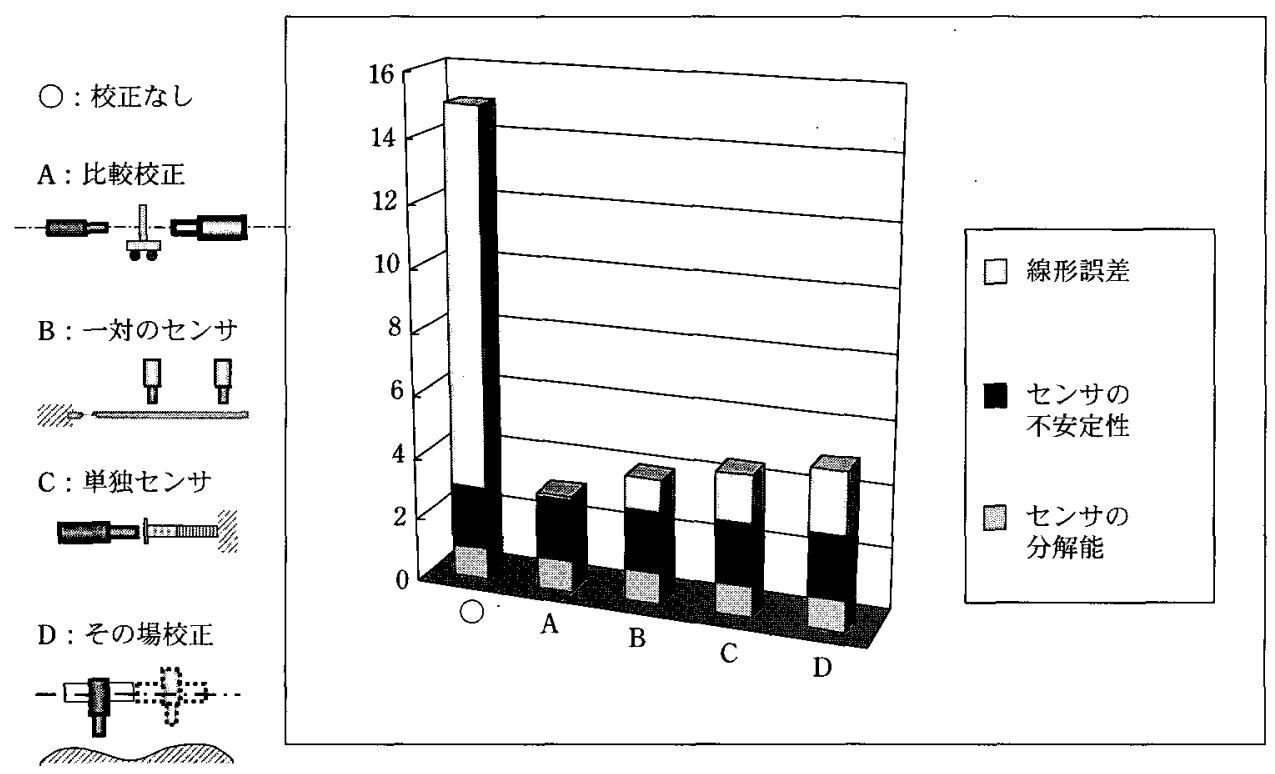

図 8 校正結果の不確かさのレベル

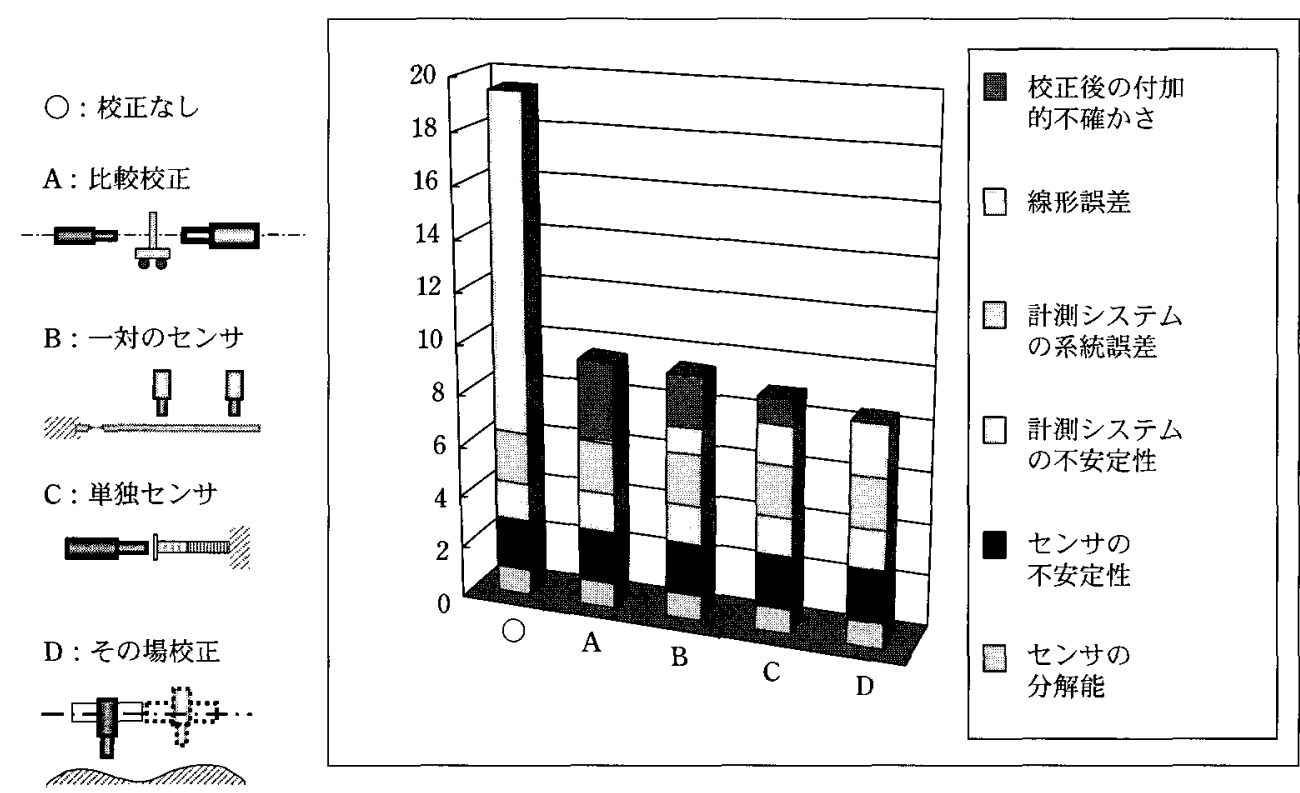

図 9 補正結果の不確かさのレベル

の校正データの確からしさこそ重要になる.

\section{2 補正結果の不確かさ}

形状測定結果の補正が目的であれば，センサの校正後に それを補正に使うまでの経過時間，校正システムから測定 システムへセンサを移設するときの取り外し，センサの移 動，センサの取り付けに伴う不確かさの要因増加を考虑し なければならない。それを追加して，補正の確からしさを 定性的に評価すると図 9 のように表される.

比較校正の場合, 時間経過も，七ンサの移動距離も一番 大きくなり，センサの取り付け状態も変化する可能性が高 い.これに対して，一対のセンサの校正は計測システムと
同じ環境で実施でき，単独センサの自立校正では，場合に よっては計測システムに取り付けたままのセンサを校正で きる，さらに，その場校正になると計測システムでのセン サ出力そのものから，センサの線形䛊差の補正結果が得ら れる。また，たとえどのように確かな校正デー夕による補 正ができても, 計測結果の確からしさはその繰り返し誤差 の大きさを超えることはできない. したがって, 測定結果 の確からしさをいうなら, 図 9 のその場校正以外の場合に は，さらに測定の繰り返し誤差による不確かさも加わるこ とになる。

走査誤差の繰り返しが形状测定結果の信頼性の一つの限 界であるとすれば，その場校正による線形誤差の補正がロ 

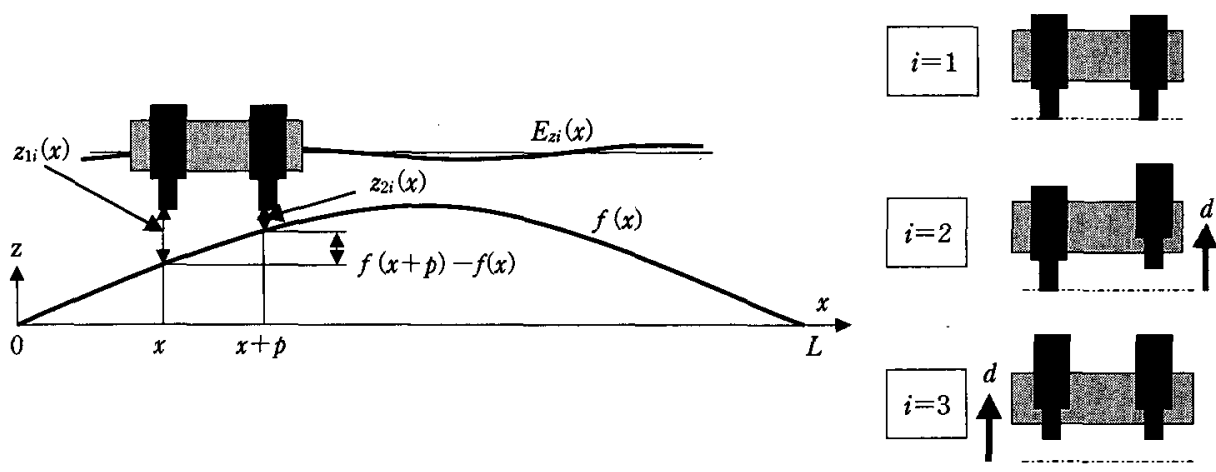

图 102 点法システムにおけるその場校正

バスト性の一つの限界を与える。

\section{3 走查運動の繰り返し性を超えて}

形状測定の繰り返し性を悪くする要因として, 環境およ びセンサの安定性の不足と, 测定のための走查運動の絽り 返し誤差がある。このうち，走查誤差の繰り返し誤差の影 響のない方法として, 2 点法, 3 点法など複数のプローブ を同時に走査して基準を計算で作り出すソフトウェアデー タムの利用が知られている.

しかし, 上述のその場校正法が測定の繰り返し（主とし て, 走査運動誤差の繰り返しに依存）に左右されるので, 線形誤差の補正まで含めた場合の確からしさの向上にはつ ながらない.

そこで, 走査の繰り返しを必要としないその場校正法が 求められることになる.そのためには，2 点法を例に挙げ ると, 図 10 のように, 2 点法の測定を個々のプローブの 縦方向シフトと組み合わせて, 3 回繰り返す方法があ る3).

理諭上この方法で, 走查運動誤差の影響を受けない 2 点 法の形状测定の繰り返し性（主として偶然誤差に左右され る）の限界まで，確からしさが高まることになる。

\section{5.おわりに}

精密測定の領域で, 評価すべき形状誤差, 比較対象とな る計測の基準，比較に使うセンサの校正誤差がほぼ同レベ ルにあり，どれかを無視して他方を同定することができな
い状況が增えている。

このような状況は, ナノレベルの精度領域で特に生じや すく,この領域ではまた, 高精度の基準との比較校正で得 た校正結果が必ずしもそれによる形状測定結果の確からし さを高めてくれる保証はない。

したがって，費用対効果を考えるとき，形状計測のため の補正に校正結果を必要とするユーザにとっては，その場 校正法の利用価値が高くなる。

また， 2 点法， 3 点法などの能力を最大限に生かすため にも，それぞれの手法における繰り返し测定デー夕に基づ くその場校正法が有効である。

\section{参 考 文 献}

1) S. Kiyono, et al. : In-situ self calibration of nano-metrological sensors and its uncertainty, Proc. of ISIST '2002, 18-22 Aug. Jinan, China (2002) 2-013-020.

2）奥山栄樹ほか：複数の測定子を用いた真直度測定法における 測定子校正誤差の不揃いの影響, 日本機械学会論文集 (C), 60, 577 (1994) 3144.

3）清野 慧: ソフトウェアデータムの実用化に问けて，2003 年 度精密工学会春期大会学術講演会講演論文集 (2003) 459 .

4) D. G. Chetwynd, et al. : X-ray interferometer calibration of microdisplacement transducers, J. Phys. E : Sci. Instrum. 16, (1983) 871.

5）清野 慧ほか：変位計の線形誤差の自律校正法, 精密工学会 誌, 59 (1993) 2043.

6）清野 慧ほか：幾何学量センサのその場自律校正法の研究， 精密工学会誌, 63, 10 (1997) 1417.

7) Shizou Zhang, et al.: An absolute calibration method for displacement sensors, Measurement, 29, (2001) 11. 